Article

\title{
Short-Term Response of Sasa Dwarf Bamboo to a Change of Soil Nitrogen Fertility in a Forest Ecosystem in Northern Hokkaido, Japan
}

\author{
Tsunehiro Watanabe ${ }^{1,2, *}$, Karibu Fukuzawa ${ }^{3,+}$ and Hideaki Shibata ${ }^{1,+}$ \\ 1 Field Science Center for Northern Biosphere, Hokkaido University, Kita 9 Nishi 9, Kita-ku, Sapporo, \\ Hokkaido 060-0809, Japan; shiba@fsc.hokudai.ac.jp \\ 2 Graduate School for Environmental Science, Hokkaido University, Kita10, Nishi 5, Kita-ku, Sapporo, \\ Hokkaido 060-0810, Japan \\ 3 Field Science Center for Northern Biosphere, Hokkaido University, 483 Otoineppu, Otoineppu, \\ Hokkaido 098-2501, Japan; caribu@fsc.hokudai.ac.jp \\ * Correspondence: watanabetsune@gmail.com; Tel.: +81-11-706-3653; Fax: +81-11-706-3450 \\ + These authors contributed equally to this work
}

Academic Editor: Maurizio Chiurazzi

Received: 11 January 2016; Accepted: 8 April 2016; Published: 14 April 2016

\begin{abstract}
In forest ecosystems, a change of soil nitrogen $(\mathrm{N})$ cycling after disturbance is regulated by various factors. Sasa dwarf bamboo (hereafter referred to as Sasa) is an understory plant that grows thickly on the forest floor in northern Hokkaido, Japan. However, the ecosystem function of Sasa after disturbances in the soil $\mathrm{N}$ cycling is not fully understood. The purpose of this study was to determine the short-term response of Sasa to a change of soil $\mathrm{N}$ fertility. Biomass, litterfall, litter decomposition, soil $\mathrm{N}$ pool, and $\mathrm{N}$ leaching from soil were measured in control, and low- $\left(5 \mathrm{~g} \mathrm{~N} \mathrm{~m}^{-2}\right.$ year $\left.^{-1}\right)$ and high-N (15 $\mathrm{g} \mathrm{N} \mathrm{m}^{-2}$ year $\left.^{-1}\right)$ addition plots. Sasa immobilized much $\mathrm{N}$ as the soil $\mathrm{N}$ fertility increased. However, the leaf $\mathrm{N}$ concentration in aboveground biomass did not increase, suggesting that the $\mathrm{N}$ in leaves was maintained because of the increase of leaf biomass. As a result, the decomposition and mineralization rates of the produced litter before and after $\mathrm{N}$ addition were comparable among plots, even though the soil inorganic $\mathrm{N}$ fertility increased greatly. These results suggest that immediate response of Sasa to an increase of soil inorganic $\mathrm{N}$ mitigates the excess $\mathrm{N}$ leaching from soil.
\end{abstract}

Keywords: biomass; litter decomposition; nitrogen addition experiment; nitrogen cycling; understory plant

\section{Introduction}

Forests supply a variety of ecosystem services, such as the maintenance of water regulation, primary production, carbon (C) sequestration, and biodiversity, which are based on complex balances that occur in forest ecosystems. However, human activities, such as logging, fossil fuel consumption, and fertilizer inputs to farmland, degrade ecosystem services by altering the amount of $\mathrm{C}$ dioxide and nitrogen $(\mathrm{N})$ oxide emissions, as well as the material cycling between plants and soil in forest ecosystems [1-6]. Notably, anthropogenic disturbances resulting from increased economic development have been predicted to degrade ecosystem services in East Asia [3,4,7,8].

An increase of atmospheric $\mathrm{N}$ deposition is one of the main environmental events significantly impacting forest and aquatic ecosystems [3,5,6]. Previous studies have shown that atmospheric N deposition causes an increase of the net primary production of forests $[1,9,10]$, a change of the $\mathrm{N}$ concentration and nutrient balances of green and senescent leaves, and $\mathrm{C}$ and $\mathrm{N}$ mineralization from litter [11-13] because $\mathrm{N}$ is generally limited in temperate forest ecosystems [14]. An increase of the leaf $\mathrm{N}$ concentration and decrease of the soil $\mathrm{C} / \mathrm{N}$ ratio results in a higher risk of $\mathrm{N}$ 
leaching from soil to streams by enhancing microbial litter decomposition, $\mathrm{N}$ mineralization and nitrification $[2,12,13,15]$. Recently, some studies have reported the impacts of increased $\mathrm{N}$ deposition on understory plants [16-20]. For example, the numbers of bryophytes and lichens, which function as $\mathrm{N}$ sinks, decreased because of increased atmospheric $\mathrm{N}$ deposition, whereas the numbers of herbaceous plants, such as Gramineae, increased [20-22]. These results suggest that the initial responses of forest ecosystems to an increase of atmospheric $\mathrm{N}$ deposition differ significantly depending on the amount of the original $\mathrm{N}$ deposition and the sensitivity of plant species including understory plants to external $\mathrm{N}$. However, the responses of understory plants, especially in the litter dynamics to the change in soil $\mathrm{N}$ fertility are not fully understood.

Northern Hokkaido, Japan, has relatively low atmospheric $\mathrm{N}$ deposition (ca. $2.3 \mathrm{~kg} \mathrm{~N} \mathrm{~m}^{-2}$ year $^{-1}$ ) compared with other regions in Japan [23]. Sasa dwarf bamboo (Sasa senanensis, Gramineae) (hereafter referred to as Sasa) is a common understory plant that is distributed densely on the forest floor in this region. Sasa, a clonal plant, produces a rhizome and reproduces asexually. It has been indicated that Sasa, having a wide distribution, not only has a negative effect on the natural regeneration of tree plants, but is also important for understanding ecosystem function [24-26]. Sasa litterfall accounted for $30 \%$ of the total litterfall in a natural forest, and that the litter decomposed more slowly than tree leaf litter because of its high silicate content [26]. It has also been reported that Sasa mitigates increases of soil inorganic $N$ [27-29] and $N$ leaching from soil to streams [30,31] because of the rapid annual increment of its aboveground and belowground biomass. These results indicate that Sasa take up the most of increased soil inorganic $\mathrm{N}$ after disturbances such as atmospheric $\mathrm{N}$ deposition or forest management treatments, suggesting that the change of soil $\mathrm{N}$ fertility influence on Sasa litter dynamics. However, it is not known how the Sasa N sink and Sasa litter dynamics change in response to increased $\mathrm{N}$ uptake.

Here, we aimed to determine the short-term response of Sasa to a change of soil $\mathrm{N}$ fertility. We hypothesized that: (1-1) as soil $\mathrm{N}$ fertility increases, the leaf litter $\mathrm{N}$ concentration would increase because of increased $\mathrm{N}$ uptake by Sasa; (1-2) the decomposition rate of Sasa leaf litter would increase in response to increases of soil $\mathrm{N}$ fertility and the litter $\mathrm{N}$ concentration; and (2) as soil $\mathrm{N}$ fertility increases, the extent of $\mathrm{N}$ leaching from soil would be mitigated by the increase of $\mathrm{N}$ uptake by Sasa. To test these hypotheses, we conducted a plot-level $\mathrm{N}$ addition experiment in a temperate forest in northern Hokkaido, Japan.

\section{Results}

\subsection{The Response of Sasa and Soil to a Change of Soil N Fertility}

$\mathrm{N}$ amount effects by $\mathrm{N}$ addition were detected for leaf in Sasa aboveground biomass except for current leaf biomass (Table 1). They were significantly higher in the high-N plot than in the other plots in $2009(P<0.05)$ (Table 1$)$. In contrast, $\mathrm{N}$ amount effects were not found for the $\mathrm{N}$ concentration in each organ of the Sasa aboveground biomass (Table S2). Year effect was detected for soil inorganic $\mathrm{N}$ $(P<0.05)$ (Table 1$)$.

In the litter decomposition experiment, the initial N concentrations of Sasa leaf litter were not significantly differences among plots in each collected year (Table 2). After one year of decomposition, the dry mass remaining of Sasa leaf litter were not significantly differences among plots in each decomposition period (Table 3). In $\mathrm{N}$ mass remaining, the highest value occurred in the high-N plot during the decomposition period from November 2007 to $2008(P<0.05)$, and the N mass remaining during the decomposition period from November 2008 to 2009 was significantly higher in low-N plot than in control plot. $\mathrm{N}$ amount effects were absent for the litterfall amount and the $\mathrm{N}$ concentration in litter fall (Table S4). 
Table 1. Number, biomass, and biomass $\mathrm{N}$ in leaf (Total, current, and previous) in Sasa aboveground and soil inorganic $\mathrm{N}$ in control, and low- and high-N plots after $\mathrm{N}$ addition with $P$ values of two-way ANOVA (year, $\mathrm{N}$ amount, and the interaction).

\begin{tabular}{|c|c|c|c|c|c|c|c|c|c|c|c|}
\hline \multirow{2}{*}{ Year } & \multicolumn{3}{|c|}{ Control Plot } & \multicolumn{3}{|c|}{ Low-N Plot } & \multicolumn{3}{|c|}{ High-N Plot } & \multirow{2}{*}{$\begin{array}{l}\text { Two-Way } \\
\text { ANOVA }\end{array}$} & \multirow{2}{*}{$P$ Value } \\
\hline & Mean & SD & & Mean & SD & & Mean & SD & & & \\
\hline \multicolumn{12}{|c|}{ Total leaf number (number $\mathrm{m}^{-2}$ ) } \\
\hline 1 year After & 263 & 143 & $\mathrm{aA}^{(1)}$ & 289 & 264 & $\mathrm{aA}$ & 619 & 372 & $\mathrm{aA}$ & Year $(Y)$ & ns \\
\hline 2 year After & 300 & 197 & $\mathrm{bA}$ & 275 & 116 & $\mathrm{bA}$ & 697 & 209 & $\mathrm{aA}$ & $\begin{array}{l}\text { Treatment }(\mathrm{T}) \\
\text { Interaction } \mathrm{T} \times \mathrm{Y}\end{array}$ & $\begin{array}{c}<0.01 \\
\mathrm{~ns}\end{array}$ \\
\hline \multicolumn{12}{|c|}{ Total leaf biomass (g DW m²) } \\
\hline 1 year After & 321 & 137 & $\mathrm{aA}$ & 297 & 205 & $\mathrm{aA}$ & 596 & 316 & $\mathrm{aA}$ & Year $(Y)$ & ns \\
\hline 2 year After & 218 & 108 & $\mathrm{bA}$ & 205 & 67 & $\mathrm{bA}$ & 512 & 167 & $\mathrm{aA}$ & $\begin{array}{l}\text { Treatment }(\mathrm{T}) \\
\text { Interaction } \mathrm{T} \times \mathrm{Y}\end{array}$ & $\begin{array}{c}<0.01 \\
\text { ns }\end{array}$ \\
\hline \multicolumn{12}{|c|}{ Total leaf biomass $\mathrm{N}\left(\mathrm{g} \mathrm{N} \mathrm{m}^{-2}\right)$} \\
\hline 1 year After & 6.1 & 2.7 & $\mathrm{aA}$ & 5.5 & 4.3 & $\mathrm{aA}$ & 11.4 & 6.2 & $\mathrm{aA}$ & Year $(Y)$ & ns \\
\hline 2 year After & 4.5 & 1.8 & $\mathrm{bA}$ & 3.9 & 1.3 & $\mathrm{bA}$ & 10.8 & 3.6 & $\mathrm{aA}$ & $\begin{array}{l}\text { Treatment }(\mathrm{T}) \\
\text { Interaction } \mathrm{T} \times \mathrm{Y}\end{array}$ & $\begin{array}{c}<0.01 \\
\text { ns }\end{array}$ \\
\hline \multicolumn{12}{|c|}{ Current leaf number (number $\mathrm{m}^{-2}$ ) } \\
\hline $\begin{array}{l}1 \text { year After } \\
2 \text { year After }\end{array}$ & $\begin{array}{c}71 \\
155\end{array}$ & $\begin{array}{l}47 \\
64\end{array}$ & $\begin{array}{l}\mathrm{aA} \\
\mathrm{bA}\end{array}$ & $\begin{array}{l}107 \\
115\end{array}$ & $\begin{array}{c}148 \\
83\end{array}$ & $\begin{array}{l}\mathrm{aA} \\
\mathrm{bA}\end{array}$ & $\begin{array}{l}165 \\
300\end{array}$ & $\begin{array}{c}103 \\
90\end{array}$ & $\begin{array}{l}\mathrm{aA} \\
\mathrm{aA}\end{array}$ & $\begin{array}{l}\text { Year }(\mathrm{Y}) \\
\text { Treatment }(\mathrm{T}) \\
\text { Interaction } \mathrm{T} \times \mathrm{Y}\end{array}$ & $\begin{array}{c}\mathrm{ns} \\
<0.05 \\
\mathrm{~ns}\end{array}$ \\
\hline \multicolumn{12}{|c|}{ Current leaf biomass (g DW m²) } \\
\hline $\begin{array}{l}1 \text { year After } \\
2 \text { year After }\end{array}$ & $\begin{array}{c}90 \\
107\end{array}$ & $\begin{array}{l}44 \\
19\end{array}$ & $\begin{array}{l}\mathrm{aA} \\
\mathrm{aA}\end{array}$ & $\begin{array}{l}87 \\
80\end{array}$ & $\begin{array}{c}113 \\
56\end{array}$ & $\begin{array}{l}\mathrm{aA} \\
\mathrm{aA}\end{array}$ & $\begin{array}{l}129 \\
150\end{array}$ & $\begin{array}{l}87 \\
72\end{array}$ & $\begin{array}{l}\mathrm{aA} \\
\mathrm{aA}\end{array}$ & $\begin{array}{l}\text { Year }(\mathrm{Y}) \\
\text { Treatment }(\mathrm{T}) \\
\text { Interaction } \mathrm{T} \times \mathrm{Y}\end{array}$ & $\begin{array}{c}\text { ns } \\
0.0579 \\
\text { ns }\end{array}$ \\
\hline \multicolumn{12}{|c|}{ Current leaf biomass $\mathrm{N}\left(\mathrm{g} \mathrm{N} \mathrm{m}^{-2}\right)$} \\
\hline $\begin{array}{l}1 \text { year After } \\
2 \text { year After }\end{array}$ & $\begin{array}{l}1.9 \\
2.6\end{array}$ & $\begin{array}{l}1.0 \\
0.3\end{array}$ & $\begin{array}{l}\mathrm{aA} \\
\mathrm{bA}\end{array}$ & $\begin{array}{l}1.8 \\
1.9\end{array}$ & $\begin{array}{l}2.4 \\
1.3\end{array}$ & $\begin{array}{l}\mathrm{aA} \\
\mathrm{bA}\end{array}$ & $\begin{array}{l}3.4 \\
4.5\end{array}$ & $\begin{array}{l}2.1 \\
1.4\end{array}$ & $\begin{array}{l}\mathrm{aA} \\
\mathrm{aA}\end{array}$ & $\begin{array}{l}\text { Year }(\mathrm{Y}) \\
\text { Treatment }(\mathrm{T}) \\
\text { Interaction } \mathrm{T} \times \mathrm{Y}\end{array}$ & $\begin{array}{c}\text { ns } \\
<0.05 \\
\text { ns }\end{array}$ \\
\hline \multicolumn{12}{|c|}{ Previous leaf number (number $\mathrm{m}^{-2}$ ) } \\
\hline $\begin{array}{l}1 \text { year After } \\
2 \text { year After }\end{array}$ & $\begin{array}{l}192 \\
145\end{array}$ & $\begin{array}{l}100 \\
140\end{array}$ & $\begin{array}{l}\mathrm{aA} \\
\mathrm{bA}\end{array}$ & $\begin{array}{l}182 \\
160\end{array}$ & $\begin{array}{c}116 \\
53\end{array}$ & $\begin{array}{l}\mathrm{aA} \\
\mathrm{bA}\end{array}$ & $\begin{array}{l}454 \\
397\end{array}$ & $\begin{array}{l}271 \\
136\end{array}$ & $\begin{array}{l}\mathrm{aA} \\
\mathrm{aA}\end{array}$ & $\begin{array}{l}\text { Year }(\mathrm{Y}) \\
\text { Treatment }(\mathrm{T}) \\
\text { Interaction } \mathrm{T} \times \mathrm{Y}\end{array}$ & $\begin{array}{c}\text { ns } \\
<0.01 \\
\text { ns }\end{array}$ \\
\hline \multicolumn{12}{|c|}{ Previous leaf biomass $\left(\mathrm{g} \mathrm{DW} \mathrm{m} \mathrm{m}^{-2}\right)$} \\
\hline $\begin{array}{l}1 \text { year After } \\
2 \text { year After }\end{array}$ & $\begin{array}{l}231 \\
111\end{array}$ & $\begin{array}{l}96 \\
98\end{array}$ & $\begin{array}{l}\mathrm{aA} \\
\mathrm{bA}\end{array}$ & $\begin{array}{l}210 \\
125\end{array}$ & $\begin{array}{l}98 \\
42\end{array}$ & $\begin{array}{l}\mathrm{aA} \\
\mathrm{bA}\end{array}$ & $\begin{array}{l}446 \\
315\end{array}$ & $\begin{array}{l}230 \\
103\end{array}$ & $\begin{array}{l}\mathrm{aA} \\
\mathrm{aA}\end{array}$ & $\begin{array}{l}\text { Year }(\mathrm{Y}) \\
\text { Treatment }(\mathrm{T}) \\
\text { Interaction } \mathrm{T} \times \mathrm{Y}\end{array}$ & $\begin{array}{c}\text { ns } \\
<0.01 \\
\text { ns }\end{array}$ \\
\hline \multicolumn{12}{|c|}{ Previous leaf biomass $\mathrm{N}\left(\mathrm{g} \mathrm{N} \mathrm{m}^{-2}\right)$} \\
\hline $\begin{array}{l}1 \text { year After } \\
2 \text { year After }\end{array}$ & $\begin{array}{l}4.1 \\
1.9\end{array}$ & $\begin{array}{l}1.8 \\
1.7\end{array}$ & $\begin{array}{l}\mathrm{aA} \\
\mathrm{bA}\end{array}$ & $\begin{array}{l}3.6 \\
2.1\end{array}$ & $\begin{array}{l}2.1 \\
0.6\end{array}$ & $\begin{array}{l}\mathrm{aA} \\
\mathrm{bA}\end{array}$ & $\begin{array}{l}8.0 \\
6.3\end{array}$ & $\begin{array}{l}4.1 \\
2.4\end{array}$ & $\begin{array}{l}\mathrm{aA} \\
\mathrm{aA}\end{array}$ & $\begin{array}{l}\text { Year }(\mathrm{Y}) \\
\text { Treatment }(\mathrm{T}) \\
\text { Interaction } \mathrm{T} \times \mathrm{Y}\end{array}$ & $\begin{array}{c}\text { ns } \\
<0.01 \\
\text { ns }\end{array}$ \\
\hline \multicolumn{12}{|c|}{ Soil inorganic $\mathrm{N}\left(\mathrm{NH}_{4}{ }^{+}\right.$and $\left.\mathrm{NO}_{3}^{-}\right)$amount $\left(\mathrm{g} \mathrm{m}^{-2}\right)$} \\
\hline 1 year After & 5.43 & 1.48 & $\mathrm{aA}$ & 3.92 & 0.91 & $\mathrm{aA}$ & 3.94 & 0.73 & $\mathrm{aA}$ & Year $(Y)$ & $<0.01$ \\
\hline 2 year After & 3.17 & 1.33 & $\mathrm{aA}$ & 2.06 & 0.53 & $\mathrm{aB}$ & 3.17 & 0.83 & $\mathrm{aA}$ & $\begin{array}{l}\text { Treatment }(\mathrm{T}) \\
\text { Interaction } \mathrm{T} \times \mathrm{Y}\end{array}$ & $\begin{array}{l}\text { ns } \\
\text { ns }\end{array}$ \\
\hline
\end{tabular}

September 2008 and 2009 are referred to as 1 year and 2 year, respectively. ${ }^{(1)}$ Different lower-case letters indicate significant differences among plots in each year $(P<0.05$, Tukey's HSD); different capital letters indicate significant differences between years in each plot $(P<0.05, t$-test $)$ in each category; and ns means no significant differences. 
Table 2. Initial leaf litter $\mathrm{N}$ concentration for litter decomposition experiment before and after $\mathrm{N}$ addition in control, and low- and high-N plots with $P$ values of the one-way ANOVA.

\begin{tabular}{llllllll}
\hline \multirow{2}{*}{$\begin{array}{l}\text { Collected Year } \\
\text { of Used Litter }\end{array}$} & \multicolumn{4}{c}{ Control } & \multicolumn{2}{c}{ Low-N } & \multicolumn{2}{c}{ High-N } & \multirow{2}{*}{$\begin{array}{c}\text { One-Way } \\
\text { Mean }\end{array}$} & SD & Mean & SD & Mean & SD & ANOVA $\boldsymbol{P}$ Value \\
\hline \multicolumn{8}{c}{ Initial leaf litter N concentration $\left(\mathrm{mg} \mathrm{g}^{-1}\right)$} \\
October (2007) & 10.4 & 1.8 & 11.2 & 3.0 & 8.6 & 2.2 & ns \\
October (2008) & 12.1 & 1.7 & 11.2 & 1.3 & 12.4 & 1.1 & $\mathrm{~ns}$ \\
\hline
\end{tabular}

ns means no significant difference.

Table 3. Dry mass and N mass remaining after one-year decomposition in each decomposition period in control, and low- and high-N plots with $P$ values of the one-way ANOVA.

\begin{tabular}{|c|c|c|c|c|c|c|c|c|c|c|c|}
\hline \multirow{2}{*}{$\begin{array}{l}\text { Collected } \\
\text { Year of } \\
\text { Used Litter }\end{array}$} & \multirow{2}{*}{$\begin{array}{c}\text { Decomposition } \\
\text { Period }\end{array}$} & \multicolumn{3}{|c|}{ Control } & \multicolumn{3}{|c|}{ Low-N } & \multicolumn{3}{|c|}{ High-N } & \multirow{2}{*}{$\begin{array}{c}\text { One-Way } \\
\text { ANOVA } \\
P \text { Value }\end{array}$} \\
\hline & & Mean & SD & & Mean & SD & & Mean & SD & & \\
\hline \multicolumn{12}{|c|}{ Dry mass remaining $(\%)$} \\
\hline $\begin{array}{l}\text { October } \\
(2007)\end{array}$ & $\begin{array}{l}\text { November } 2007 \\
\text { to } 2008\end{array}$ & 74.1 & 4.5 & $\mathrm{a}^{(1)}$ & 75.9 & 3.0 & a & 74.2 & 3.3 & a & ns \\
\hline $\begin{array}{l}\text { October } \\
(2008)\end{array}$ & $\begin{array}{c}\text { November } 2008 \\
\text { to } 2009\end{array}$ & 72.1 & 3.3 & a & 71.5 & 4.3 & a & 69.7 & 4.4 & a & ns \\
\hline \multicolumn{12}{|c|}{$\mathrm{N}$ mass remaining $(\%)$} \\
\hline $\begin{array}{l}\text { October } \\
\text { (2007) }\end{array}$ & $\begin{array}{l}\text { November } 2007 \\
\text { to } 2008\end{array}$ & 108.8 & 22.1 & $b$ & 106.5 & 28.9 & $b$ & 140.6 & 39.3 & a & $<0.05$ \\
\hline $\begin{array}{l}\text { October } \\
(2008)\end{array}$ & $\begin{array}{l}\text { November } 2008 \\
\text { to } 2009\end{array}$ & 82.9 & 17.3 & $\mathrm{~b}$ & 103.6 & 20.0 & a & 92.9 & 11.4 & $\mathrm{ab}$ & $<0.05$ \\
\hline
\end{tabular}

\subsection{Estimation of the $N$ Budget}

The amount of annual $\mathrm{N}$ leaching in the high- $\mathrm{N}$ plot after the $\mathrm{N}$ addition was significantly higher than that of the other plots $(P<0.05)$ (Figure 1). The amounts of annual $\mathrm{N}$ leaching in the low- and high-N plots were $2.2 \%$ and $15 \%$ of the annual $\mathrm{N}$ input, respectively (Figure 1 and Table 4 ). The amounts of retained $\mathrm{N}$ in the whole Sasa and soil system in the low- and high-N plots were 4.89 and $12.8 \mathrm{~g} \mathrm{~N} \mathrm{~m}^{-2}$ year $^{-1}$, or equivalent to $97.8 \%$ and $85 \%$ of the annual $\mathrm{N}$ input, respectively (Table 4 ). Regarding the measured $\mathrm{N}$ storage in the Sasa and soil system, the total net changes in the low- and high- $\mathrm{N}$ plots were -3.56 and $9.14 \mathrm{~g} \mathrm{~N} \mathrm{~m}^{-2}$, respectively (i.e., sum of the net $\mathrm{N}$ storage except the estimated storage in Table 4). In the high-N plot, $57 \%$ of the net change of the total measured $\mathrm{N}$ storage mass resulted from Sasa aboveground biomass $\left(5.76 \mathrm{~g} \mathrm{~N} \mathrm{~m}^{-2}\right)$. The estimated amounts of unmeasured N storage ("Estimated N storage" in Table 4) in the Sasa and soil system in the low- and high-N plots were 8.11 and $2.72 \mathrm{~g} \mathrm{~N} \mathrm{~m}^{-2}$, respectively (Table 4). 


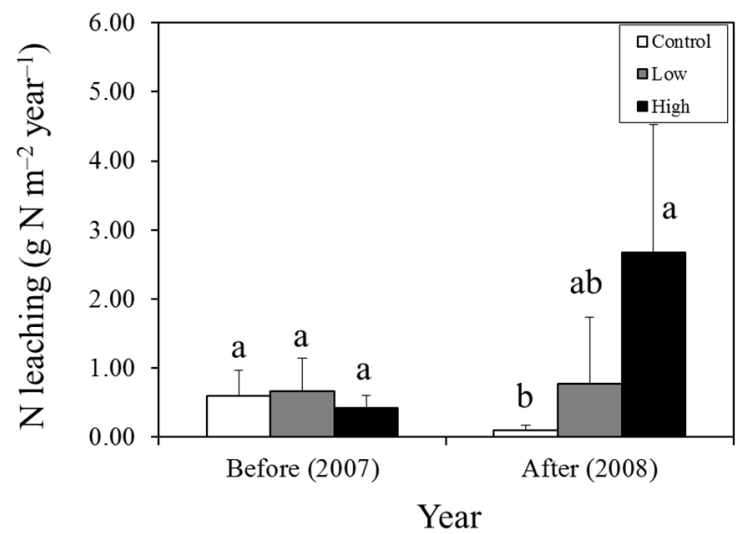

Figure 1. Inorganic N leaching in control, low-, and high-N plots before (2007) and after (2008) N addition. The results of the one-way ANOVA among plots in each year are shown in the graph. The $\mathrm{N}$ leaching amount of before and after $\mathrm{N}$ addition is calculated as sum of the period from August 2007 to June 2008 and sum of the period from June 2008 to June 2009, respectively. Different lower-case letters indicate significant differences among plots $(P<0.05$, Tukey's HSD).

Table 4. $\mathrm{N}$ input-output, measured $\mathrm{N}$ storage, and estimated $\mathrm{N}$ storage in each year and their net change in low- and high-N plots.

\begin{tabular}{|c|c|c|c|c|c|c|}
\hline \multirow{2}{*}{ Component } & \multicolumn{2}{|c|}{ Low-N Plot } & \multirow{2}{*}{$\begin{array}{l}\text { Net Change } \\
\left(\mathrm{g} \mathrm{N} \mathrm{m}^{-2}\right)\end{array}$} & \multicolumn{2}{|c|}{ High-N Plot } & \multirow{2}{*}{$\begin{array}{l}\text { Net Change } \\
\left(\mathrm{g} \mathrm{N} \mathrm{m}^{-2}\right)\end{array}$} \\
\hline & Before & After & & Before & After & \\
\hline \multicolumn{7}{|c|}{$\mathrm{N}$ input-output ( $\mathrm{g} \mathrm{N} \mathrm{m}^{-2}$ year $^{-1}$ ) } \\
\hline $\mathrm{N}$ input & 0 & 5 & 5 & 0 & 15 & 15 \\
\hline N leaching & 0.66 & 0.77 & 0.11 & 0.42 & 2.67 & 2.25 \\
\hline $\mathrm{N}$ retention & & & 4.89 & & & 12.75 \\
\hline \multicolumn{7}{|c|}{$\mathrm{N}$ storage $\left(\mathrm{g} \mathrm{N} \mathrm{m}^{-2}\right)$} \\
\hline Aboveground biomass $\mathrm{N}$ & 15.68 & 9.26 & -6.42 & 13.36 & 19.12 & 5.76 \\
\hline Belowground biomass N & 4.59 & 7.29 & 2.71 & 5.54 & 8.12 & 2.58 \\
\hline $\mathrm{N}$ mass remaining in litter & 0.85 & 1.18 & 0.33 & 1.37 & 1.73 & 0.36 \\
\hline Soil inorganic $\mathrm{N}$ & 4.10 & 3.92 & -0.18 & 3.50 & 3.94 & 0.44 \\
\hline Estimated $\mathrm{N}$ storage & & & 8.11 & & & 2.72 \\
\hline
\end{tabular}

$\mathrm{N}$ retention is calculated by subtracting $\mathrm{N}$ leaching from $\mathrm{N}$ input in net change in each plot (Equation (2)); $\mathrm{N}$ mass remaining in litter $=$ Litterfall $\mathrm{N}$ amount $\left(\mathrm{g} \mathrm{N} \mathrm{m}^{-2}\right.$ year $\left.{ }^{-1}\right) \times \mathrm{N}$ mass remaining $(\%)$ after one-year decomposition/100. Estimated $\mathrm{N}$ storage is estimated by subtracting total in measured $\mathrm{N}$ storage from $\mathrm{N}$ retention (Equation 3).

\section{Discussion}

\subsection{Effect of Soil N Fertility Changes on the Leaf N, Biomass and Litter Decomposition}

The leaf biomass $\mathrm{N}$ increased significantly in the high- $\mathrm{N}$ plot compared with the other plots in 2009 (Table 1). However, there was no significant $\mathrm{N}$ amount effect on the leaf $\mathrm{N}$ concentration in the Sasa aboveground biomass and the litter (Tables S2 and S4), suggesting that the leaf N concentrations in the aboveground biomass and litter did not change, even though the amount of $\mathrm{N}$ taken up by the Sasa aboveground biomass increased rapidly in response to the short-term increase of soil $\mathrm{N}$ fertility. Previous studies have indicated that after $\mathrm{N}$ addition, the leaf $\mathrm{N}$ concentration increased by the increase of the amount of $\mathrm{N}$ uptake with the decrease of $\mathrm{N}$ resorption from green- to senescent-leaves because of the mitigation of the soil $\mathrm{N}$ limit [32-38]. In such case, the $\mathrm{N}$ concentration in leaf litter result to increases [32-38]. However, in this study, the $\mathrm{N}$ concentration in leaf litter did not increase (Table S4 and Table 2), suggesting that increase of leaf production (i.e., carbon uptake by photosynthesis) compensated the increase of $\mathrm{N}$ concentration by the increase of $\mathrm{N}$ uptake in leaf. These mechanisms 
are known as dilution effects, which have also been reported in $\mathrm{CO}_{2}$ fertilization experiments [39,40]. As a result, it was suggested that the litter $\mathrm{N}$ concentration after $\mathrm{N}$ addition was also maintained by those dilution effects (Table 2).

Results of one-year litter decomposition in both decomposition periods revealed that there were no significant $\mathrm{N}$ amount effects on the dry mass remaining during each year (Table 3 ). This result indicates that the amount of $\mathrm{C}$ released by the Sasa leaf litter decomposition does not increase when the soil $\mathrm{N}$ fertility increases. The increase of the $\mathrm{N}$ concentration in leaf litter and the addition of $\mathrm{N}$ directly to the leaf litter usually enhance the decomposition of leaf litter with low lignin content, especially in the initial decomposition phase, which provides much available $C$ for microbes [41]. It has been known that the lignin concentration of the Sasa leaf litter is significantly lower than that of tree leaf litter in our studied region [26]. However, $\mathrm{N}$ addition did not affect the $\mathrm{C}$ decomposition in the initial decomposition of Sasa leaf litter. It has also been suggested that Sasa litter with a high silicate concentration decomposes more slowly than tree leaf litter [26]. These results suggest that litter with a high concentration of a recalcitrant material, including silicate, responds less to the increase of soil $\mathrm{N}$ fertility.

The $\mathrm{N}$ mass remaining during litter decomposition was maintained even after the $\mathrm{N}$ additions except for the high- and low-N plots in the decomposition period from November 2007 to 2008 and November 2008 to 2009, respectively (Table 3). In a previous study of litter decomposition, leaf litter was often decomposed rapidly in the initial decomposition phase under a high soil $\mathrm{N}$ level compared to a low soil $\mathrm{N}$ level $[41,42]$. However, in this study, the $\mathrm{N}$ did not release from Sasa leaf litter even though there were sufficient amounts of available $\mathrm{N}$ in the surrounding soil. It suggests that Sasa leaf litter has a high resistance for microbial decomposition, even in increased $\mathrm{N}$ environments, compared to other plants.

\subsection{The Response of the Sasa and Soil System to Increased Soil N Fertility}

The $\mathrm{N}$ leaching from soil increased in the high- $\mathrm{N}$ plot after the $\mathrm{N}$ addition, whereas there were no significant changes in the low-N plot compared to the control plot (Table 4). These results suggest that the threshold of $\mathrm{N}$ retention of the Sasa and soil system to cause $\mathrm{N}$ leaching would be between 5 and $15 \mathrm{~g} \mathrm{~N} \mathrm{~m}^{-2}$ year $^{-1}$. Most excess $\mathrm{N}$ was accumulated in Sasa biomass and litter layer even though the short-term increase of soil $\mathrm{N}$ fertility was large enough to cause $\mathrm{N}$ leaching from soil. Sasa immobilized much of the $\mathrm{N}$, even at the high $\mathrm{N}$ input (Table 4). In addition, some $\mathrm{N}$ was retained in the estimated $\mathrm{N}$ storage, which was not measured directly in this study (Table 4). This unmeasured component would include microbial $\mathrm{N}$ retention, $\mathrm{N}$ immobilization in decomposing litter (i.e., Oe (partly decomposed and fragmented litter layer) and Oa horizon (well-decomposed litter layer)), dissolved organic $\mathrm{N}$ (DON) and denitrification efflux. Previous studies of the ecosystem response to an increase of soil $\mathrm{N}$ fertility, such as that resulting from atmospheric $\mathrm{N}$ deposition and $\mathrm{N}$ addition experiments, have reported that biotic immobilization by microbes and abiotic immobilization by soil organic matter are important $\mathrm{N}$ sinks $[43,44]$. In a site near that of the present study, Shibata, et al. [23] reported that most of the added $\mathrm{N}\left(5 \mathrm{~g} \mathrm{~N} \mathrm{~m}^{-2}\right.$ year $\left.{ }^{-1}\right)$ was retained in the watershed during the first year. They also reported that $90 \%$ and $50 \%$ of the added ${ }^{15} \mathrm{NH}_{4}{ }^{+}$-N were quickly immobilized by microbes in the Oe/Oa layer and mineral soil, respectively. Those suggested that the estimated $\mathrm{N}$ storage in Table 4 would be mostly caused by rapid microbial $\mathrm{N}$ immobilization in decomposing litter after the $\mathrm{N}$ addition. Further quantification of the unmeasured components including DON and denitrification dynamics is necessary for better understanding.

\section{Experimental Section}

\subsection{Site Description}

This study was conducted in a conifer and broadleaf mixed forest in the Nakagawa Experimental Forest in northern Hokkaido, Japan $\left(44^{\circ} 48^{\prime} \mathrm{N}, 142^{\circ} 6^{\prime} \mathrm{E}\right)$. The forest floor is covered with understory 
plants at high density and tall plants (often reaching over $2 \mathrm{~m}$ ) predominantly consist of Sasa [24,26]. The bedrock is Cretaceous sedimentary rock. The dominant soil is a moderate dry brown forest soil [45] corresponding to Dystric Cambisol [46]. The study area has a cool-temperate climate with heavy snowfall in winter. The mean annual temperature and precipitation from 2008 to 2009 were $6.0^{\circ} \mathrm{C}$ and $1038 \mathrm{~mm}$, respectively. The winter season occurs from November to April, and precipitation increases from September to October (Figure 2). The total amount of snow, in terms of water equivalent, is approximately $445 \mathrm{~mm}$, and it accounts for $43 \%$ of the total annual precipitation. The maximum snowpack depth is approximately $2 \mathrm{~m}[23,24,26]$. The atmospheric $\mathrm{N}$ deposition in this area is about $2.3 \mathrm{~kg} \mathrm{~N} \mathrm{ha}^{-1}$ year $^{-1}$ [23].

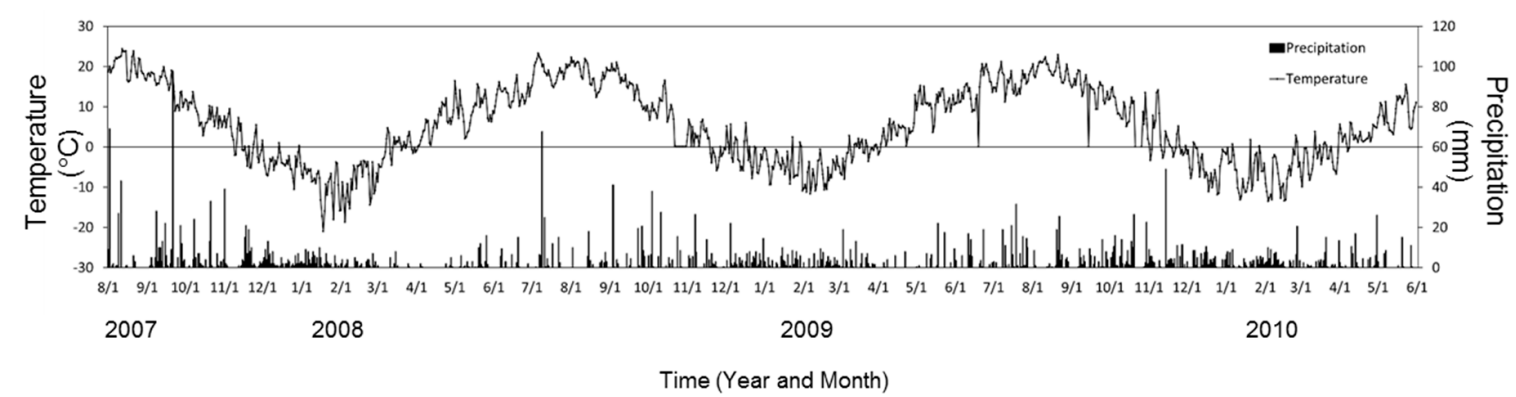

Figure 2. Mean daily precipitation and temperature measured at the Nakagawa station (AMEDAS; Automated Meteorological Data Acquisition System, Japan Meteorological Agency, http:/ / www.data.jma.go.jp) from August 2007 to May 2010.

\section{2. $N$ Addition Experiment}

The $\mathrm{N}$ addition experiment was conducted on a flat ridge (about $190 \mathrm{~m}$ above sea level) that is dominated by Sasa. The experimental period was from August 2007 to May 2010. We established three experimental plots of $\mathrm{N}$ addition: control, low- $\mathrm{N}\left(5 \mathrm{~g} \mathrm{~N} \mathrm{~m}^{-2}\right.$ year $\left.^{-1}\right)$, and high- $\mathrm{N}\left(15 \mathrm{~g} \mathrm{~N} \mathrm{~m}^{-2}\right.$ year $\left.{ }^{-1}\right)$ plots. The annual $\mathrm{N}$ addition in the low- and high- $\mathrm{N}$ plots corresponds to 22- and 65-times the atmospheric $\mathrm{N}$ deposition in this area, respectively. The amount of $\mathrm{N}$ addition in low- $\mathrm{N}$ plot was decided by the maximum $\mathrm{N}$ deposition in urban area in Japan [47]. The Sasa aboveground connects with the rhizome, through which $\mathrm{N}$ is transferred [48,49]. Therefore, $\mathrm{N}$ addition and control plots should have enough distance to avoid $\mathrm{N}$ transfer through rhizome between plots with and without $\mathrm{N}$ addition. We established $180 \mathrm{~m}^{2}$ ( $60 \mathrm{~m}$ long $\times 3 \mathrm{~m}$ wide) plots for control and $\mathrm{N}$ addition. The average distance between the plots was $20 \mathrm{~m}$. We also established four square subplots for replications in each plot. The plant species in each plot were mostly dominated by Sasa, and there were no trees in each subplot, although some canopy tree existed surrounding each subplot. The dominant tree species in the near location in this study were described in [26]. We surveyed Sasa biomass, litterfall, litter decomposition, soil $\mathrm{N}$ pool, and $\mathrm{N}$ leaching from soil in each subplot. The area of each subplot was $4 \mathrm{~m}^{2}$, and each subplot was surrounded by a $50-\mathrm{cm}$ buffer zone. We began to add $\mathrm{N}$ in June 2008. The forest floor of the control subplots were sprayed, using a hand sprayer, with $2 \mathrm{~L}$ of deionized water, and the forest floor of the $\mathrm{N}$ addition subplots were sprayed with $2 \mathrm{~L}$ of a $\mathrm{NH}_{4} \mathrm{NO}_{3}$ solution from June to October in 2008 and 2009 ( $\mathrm{N}$ was applied five times per year). The concentration of the $\mathrm{NH}_{4} \mathrm{NO}_{3}$ solution sprayed on the low- and high-N plots was adjusted to $2000 \mathrm{mg} \mathrm{L}^{-1}$ and $6000 \mathrm{mg} \mathrm{L}^{-1}$, respectively. The application time was $3 \mathrm{~h}$. The application amount was determined by adjusting the amount of the $\mathrm{NH}_{4} \mathrm{NO}_{3}$ solution to the 3-h average precipitation from June 2007 to October 2007.

\subsection{Aboveground Biomass}

We established quadrats $(50 \mathrm{~cm} \times 50 \mathrm{~cm})$ at three corners in each subplot. We collected aboveground Sasa biomass from the surface in each quadrat in late September of 2007, 2008, and 2009 when Sasa biomass is almost at its peak. The collected Sasa biomass was divided into current- and 
previous-year leaves and culms, and their numbers were measured. The samples were brought to the laboratory, dried for $72 \mathrm{~h}$ at $70{ }^{\circ} \mathrm{C}$, and weighed.

\subsection{Litterfall}

Sasa litterfall was measured from September 2007 to May 2010. The litterfall was collected using plastic box litter traps ( $34 \mathrm{~cm}$ long $\times 49 \mathrm{~cm}$ wide $\times 15 \mathrm{~cm}$ high) covered with a nylon net (1-mm mesh). The litter traps were placed in the center of each subplot. Details regarding the method of setting the litter traps and the treatment of litterfall in winter are the same as [26]. Collected litterfall was divided into Sasa leaves and Sasa culms, and the dry weight of each litter was measured after drying for $72 \mathrm{~h}$ at $70{ }^{\circ} \mathrm{C}$.

\subsection{Litter Decomposition Experiment}

Sasa leaf litter decomposition was measured by the litterbag method [26]. The produced litter in each subplot was used for litter decomposition experiment in each subplot. We used produced leaf litter before (2007) and after (2008) $\mathrm{N}$ addition. The decomposition periods were from November 2007 to 2008 in the produced leaf litter before (October 2007) and from November 2008 to 2009 in the produced leaf litter after (October 2008). We also collected some dead Sasa leaves from the standing stock in each subplot to obtain the required amount for the litterbag experiment. Collected litter samples were air dried and mixed well. Each litterbag contained $3 \mathrm{~g}$ of air-dried leaf litter. Litterbags were placed in situ in November in each year. External $\mathrm{N}$ was sprayed to the litterbags in the period from June to October in each year. There were three litterbag replicates in each subplot. The details of the size of the litterbags and the method of setting the litterbags in the field are the same as [26]. We collected a total of 36 litterbags (three $\mathrm{N}$ addition plots $\times$ four subplots $\times$ three replicates) in each year. The collected litterbags were transferred to the laboratory. After the soil and plants around the bag were carefully removed, the litter in each litterbag was dried for $72 \mathrm{~h}$ at $70{ }^{\circ} \mathrm{C}$ and weighed.

\subsection{Soil and Belowground Biomass}

Soil from a 0 to $30 \mathrm{~cm}$ depth was collected using a soil auger $(4.2-\mathrm{cm}$ inner diameter) at the same place used for sampling the aboveground biomass in late September of 2007, 2008 and 2009. The collected soil core was divided into $0-15 \mathrm{~cm}$ and $15-30 \mathrm{~cm}$ depths. Roots and coarse fragments were removed from each soil depth. The dry weight of the soil was measured after drying for $48 \mathrm{~h}$ at $105^{\circ} \mathrm{C}$ to determine the soil water content. The belowground biomass at each depth was divided into fine $(<2 \mathrm{~mm})$ and large $(>2 \mathrm{~mm})$ roots, and their dry weights were measured after drying for $72 \mathrm{~h}$ at $70^{\circ} \mathrm{C}$.

\subsection{Inorganic N Leaching}

The amount of leached inorganic $\mathrm{N}$ was measured using an ion-exchange resin (IER) bag [50]. We placed $100 \mathrm{~g}$ of IER into the nylon stocking bag and placed it in a container $(8.4 \mathrm{~cm}$ diameter, $2.7 \mathrm{~cm}$ high) made of chloroethylene. The container was buried at a $30 \mathrm{~cm}$ soil depth in each subplot. The installation periods were from August 2007 to November 2007, November 2007 to June 2008, June 2008 to November 2008, and November 2008 to June 2009. The collected IER bags were transferred to the laboratory. After the soil and plants around the IER bags were carefully removed, the IER subsamples were dried for $48 \mathrm{~h}$ at $105^{\circ} \mathrm{C}$ and weighed to determine the water content of the IER. N leaching flux $\left(\mathrm{g} \mathrm{N} \mathrm{m}^{-2}\right.$ year $\left.{ }^{-1}\right)$ from soil was quantified using the following Equation:

$$
\mathrm{N} \text { Leaching }=\mathrm{N} \text { in IER/Area }
$$

where $\mathrm{N}$ in IER indicates $\mathrm{N}$ adsorbed in the IER $(\mathrm{gN})$ and Area is the collecting areas of the IER container (8.4 cm diameter). 


\subsection{Chemical Analysis}

Dried plant samples were ground using a ball mill and analyzed for total $\mathrm{C}$ and $\mathrm{N}$ concentrations using a CHNS/O analyzer (PE2400 II; PerkinElmer Co., Ltd., Waltham, MA, USA).

Ten grams of fresh soil was extracted using $2 \mathrm{M} \mathrm{KCl}(50 \mathrm{~mL})$. The extracts were shaken for $1 \mathrm{~h}$ and filtered (Advantec No. 5B, Tokyo, Japan). The concentrations of $\mathrm{NH}_{4}{ }^{+}$and $\mathrm{NO}_{3}{ }^{-}$in the extracted solution were analyzed using an auto analyzer (AACS-4, BL-TEC Inc., Osaka, Japan).

Four grams of fresh resin was extracted using $1 \mathrm{M} \mathrm{KCl}(200 \mathrm{~mL})$. The extracts were shaken for $1 \mathrm{~h}$ and filtered. After filtration, the IER was extracted again. The extracted solution was mixed well, and the concentrations of $\mathrm{NH}_{4}{ }^{+}$and $\mathrm{NO}_{3}{ }^{-}$were analyzed using an auto analyzer.

\subsection{Statistical Analysis}

To analyze the differences among plots before $\mathrm{N}$ addition, all the data before $\mathrm{N}$ addition were tested using one-way analysis of variance (ANOVA), followed by Tukey's honestly significant difference (HSD) test when the effect was significant $(P<0.05)$. To analyze the effect of year, $\mathrm{N}$ amount, and year $\times \mathrm{N}$ amount, all the data after $\mathrm{N}$ addition were tested using two-way analysis of variance (ANOVA), followed by Tukey's honestly significant difference (HSD) test; the interaction effect was considered to be significant at $P<0.05$. When the effects were significant separately, the data were tested using one-way ANOVA for N amount effect, followed by Tukey's HSD test when the effect was significant $(P<0.05)$ and a $t$-test when the year effect was significant $(P<0.05)$. For decomposition experiment and $\mathrm{N}$ leaching, we tested the differences among plots in each year using one-way ANOVA. The statistical analyses were performed using R software ( $\mathrm{R}$ version 2.15.1, Free Software Foundation, Inc. Boston, USA. The R Foundation for Statistical Computing http://www.r-project.org/).

\subsection{Estimation of the $N$ Budget}

To clarify a quantitative alteration by $\mathrm{N}$ addition, net changes in each data ( $\mathrm{N}$ input, $\mathrm{N}$ leaching, aboveground and belowground biomass $\mathrm{N}$, litterfall $\mathrm{N}, \mathrm{N}$ mass remaining, and soil inorganic $\mathrm{N}$ ) were calculated using Equation (1). N retention was calculated using Equation (2). Based on the N budget, we estimated the $\mathrm{N}$ storage, which we was not measured directly (Equation (3)).

$$
\begin{aligned}
& \text { Net change }=\text { data after } \mathrm{N} \text { addition }- \text { data before } \mathrm{N} \text { addition } \\
& \qquad \mathrm{N} \text { retention }=\mathrm{N} \text { input }-\mathrm{N} \text { leaching } \\
& \text { Estimated } \mathrm{N} \text { storage }=\mathrm{N} \text { retention }- \text { total measured } \mathrm{N} \text { storage }
\end{aligned}
$$

where estimated $\mathrm{N}$ storage includes the unmeasured $\mathrm{N}$ component, such as microbial $\mathrm{N}$ retention, $\mathrm{N}$ immobilization in decomposing litter (i.e., Oe and Oa horizon), dissolved organic $\mathrm{N}$ and denitrification efflux. This budget was developed for one year before and after the $\mathrm{N}$ addition.

\section{Conclusions}

This study targeted Sasa, which thickly grows on the forest floor in northern Hokkaido, and it clarified the short-term response to the increase of soil $\mathrm{N}$ fertility. We found that $\mathrm{N}$ immobilization by Sasa increased when the external amount of $\mathrm{N}$ was increased at $15 \mathrm{~g} \mathrm{~N} \mathrm{~m}^{-2}$ year ${ }^{-1}$. As a result, $\mathrm{N}$ leaching from soil was minor contribution in the $\mathrm{N}$ budget, although the $\mathrm{N}$ leaching amount after $\mathrm{N}$ addition was approximately $3 \mathrm{~g} \mathrm{~N} \mathrm{~m}^{-2}$ year $^{-1}$ that was equivalent to more than 10 times the current rate of atmospheric $\mathrm{N}$ deposition (ca. $0.23 \mathrm{~g} \mathrm{~N} \mathrm{~m}^{-2}$ year $^{-1}$ ) in this region. Additionally, the $\mathrm{N}$ concentration in the aboveground biomass and leaf litter did not increase because the $\mathrm{N}$ concentration in the aboveground biomass was diluted by the increase of the leaf biomass. The decomposition and mineralization rates of Sasa leaf litter were not stimulated by $\mathrm{N}$ addition, although it has been known that the increase of litter $\mathrm{N}$ concentration and soil $\mathrm{N}$ fertility usually enhance the microbial decomposition. These results suggest that Sasa can mitigate the changes of short-term soil $\mathrm{N}$ dynamics 
and the $\mathrm{N}$ leaching from soil even at higher $\mathrm{N}$ inputs $\left(15 \mathrm{~g} \mathrm{~m}^{-2}\right.$ year $\left.{ }^{-1}\right)$ because Sasa immediately takes up the increasingly available soil $\mathrm{N}$ after disturbances. This study also suggests that organic layer is an important sink for external $\mathrm{N}$ at the low level $\mathrm{N}$ input such as $5 \mathrm{~g} \mathrm{~m}^{-2}$ year $^{-1}$. Additionally, the results suggest that the $\mathrm{N}$ retention capacity in the Sasa and soil system is significantly higher than the current rate of atmospheric $\mathrm{N}$ deposition ( $c a .0 .23 \mathrm{~g} \mathrm{~N} \mathrm{~m}^{-2}$ year $^{-1}$ ).

Previous reports indicate that tree cutting has negative effects on ecosystem structure and functioning because of the rapid changes in $\mathrm{N}$ cycling including the stimulation of $\mathrm{N}$ mineralization, nitrification and leaching [51-53]. This study indicated that a forest ecosystem with dense Sasa is more resilient to rapidly changing soil $\mathrm{N}$ availability after some natural and anthropogenic disturbances. The characteristics of Sasa, such as being a clonal plant with persistent litter, contribute to the mechanisms of mitigating dramatic changes in soil $\mathrm{N}$ dynamics. Therefore, Sasa is an important understory plant for the practice of ecosystem management including an assessment of ecosystem function in this region.

Supplementary Materials: Supplementary Materials can be found at www.mdpi.com/2223-7747/5/2/19/s1.

Acknowledgments: This study was conducted in the Nakagawa Experimental Forest of Hokkaido University, one of the core sites of the Japan Long-Term Ecological Research Network. We are grateful to all faculty and technical staff members of the Northern Forestry Research and Development Office and the Nakagawa Experimental Forest, Field Science Center for Northern Biosphere, Hokkaido University for their helpful support during the field study. We also thank Drs. Shigeru Uemura, Toshiya Yoshida, and Joo Young Cha, as well as the graduate students of the Northern Forestry Research and Development Office, Field Science Center for Northern Biosphere, Hokkaido University, for their helpful comments, discussion, and cooperation with the field work and data analysis.

Author Contributions: Tsunehiro Watanabe conducted field research, chemical analysis, statistical analysis, and wrote the paper. Karibu Fukuzawa and Hideaki Shibata provided comments on the entire research design and analysis to develop the paper.

Conflicts of Interest: The authors declare no conflict of interest.

\section{References}

1. Aber, J.D.; Nadelhoffer, K.J.; Steudler, P.; Melillo, J.M. Nitrogen saturation in northern forest ecosystems. Bioscience 1989, 39, 378-386. [CrossRef]

2. Gundersen, P.; Emmett, B.A.; Kj'naas, O.J.; Koopmans, C.J.; Tietema, A. Impact of nitrogen deposition on nitrogen cycling in forests: A synthesis of NITREX data. For. Ecol. Manage. 1998, 101, 37-55. [CrossRef]

3. Galloway, J.N.; Aber, J.D.; Erisman, J.W.; Seitzinger, S.P.; Howarth, R.W.; Cowling, E.B.; Cosby, B.J. The nitrogen cascade. BioScience 2003, 53, 341-356. [CrossRef]

4. Galloway, J.N.; Dentener, F.J.; Capone, D.G.; Boyer, E.W.; Howarth, R.W.; Seitzinger, S.P.; Asner, G.P.; Cleveland, C.C.; Green, P.A.; Holland, E.A.; et al. Nitrogen cycles: Past, present, and future. Biogeochemistry 2004, 70, 153-226. [CrossRef]

5. Fenn, M.E.; Lambert, K.F.; Blett, T.F.; Burns, D.A.; Pardo, L.H.; Lovett, G.M.; Haeuber, R.A.; Evers, D.C.; Driscoll, C.T.; Jeffries, D.S. Setting Limits: Using Air Pollution Thresholds to Protect and Restore U.S. Ecosystems; Issues in Ecology, Report No. 14; Ecological Society of America: Washington, DC, USA, 2011.

6. Shibata, H.; Branquinho, C.; McDowell, W.H.; Mitchell, M.J.; Monteith, D.T.; Tang, J.; Arvola, L.; Cruz, C.; Cusack, D.F.; Halada, L.; et al. Consequence of altered nitrogen cycles in the coupled human and ecological system under changing climate: The need for long-term and site-based research. Ambio 2015, 44, 178-193. [CrossRef] [PubMed]

7. Galloway, J.N.; Cowling, E.B. Reactive nitrogen and the world: 200 years of change. Ambio 2002, 31, 64-71. [CrossRef] [PubMed]

8. $\quad$ Fang, Y.; Gundersen, P.; Vogt, R.D.; Koba, K.; Chen, F.; Chen, X.Y.; Yoh, M. Atmospheric deposition and leaching of nitrogen in Chinese forest ecosystems. J. For. Res. 2011, 16, 341-350. [CrossRef]

9. Driscoll, C.T.; Whitall, D.; Aber, J.D.; Boyer, E.; Castro, M.; Cronan, C.; Goodale, C.L.; Groffman, P.; Hopkinson, C.; Lambert, K.; et al. Nitrogen pollution in the northeastern United States: Sources, effects, and management options. Bioscience 2003, 53, 357-374. [CrossRef] 
10. Thomas, R.Q.; Canham, C.D.; Weathers, K.C.; Goodale, C.L. Increased tree carbon storage in response to nitrogen deposition in the US. Nat. Geosci. 2010, 3, 13-17. [CrossRef]

11. Magill, A.H.; Downs, M.R.; Nadelhoffer, K.J.; Hallett, R.A.; Aber, J.D. Forest ecosystem response to four years of chronic nitrate and sulfate additions to Bear Brooks Watershed, Maine, USA. For. Ecol. Manag. 1996, 84, 29-37. [CrossRef]

12. Aber, J.D.; McDowell, W.; Nadelhoffer, K.J.; Magill, A.; Berntson, G.; Kamakea, M.; McNulty, S.; Currie, W.; Rusad, L.; Fernandez, I. Nitrogen saturation in temperate forest ecosystems: Hypotheses revisited. Bioscience 1998, 48, 921-934. [CrossRef]

13. Lovett, G.M.; Goodale, C.L. A new conceptual model of nitrogen saturation based on experimental nitrogen addition to an oak forest. Ecosystems 2011, 14, 615-631. [CrossRef]

14. Vitousek, P.M.; Howarth, R.W. Nitrogen limitation on land and in the sea: How can it occur? Biogeochemistry 1991, 13, 87-115. [CrossRef]

15. Lovett, G.M.; Weathers, K.C.; Arthur, M.A. Control of N loss from forested watersheds by soil carbon:nitrogen ratio and tree species composition. Ecosystems 2002, 5, 712-718. [CrossRef]

16. Carroll, J.A.; Johnson, D.; Morecroft, M.; Taylor, A.; Caporn, S.J.M.; Lee, J.A. The effect of long-term nitrogen additions on the bryophyte cover of upland acidic grasslands. J. Bryol. 2000, 22, 83-89. [CrossRef]

17. Haddad, N.M.; Haarstad, J.; Tilman, D. The effects of long-term nitrogen loading on grassland insect communities. Oecologia 2000, 124, 73-84. [CrossRef]

18. Lamers, L.P.M.; Bobbink, R.; Roelofs, J.G.M. Natural nitrogen filter fails in polluted raised bogs. Glob. Change Biol. 2000, 6, 583-586. [CrossRef]

19. Curtis, C.J.; Emmett, B.A.; Grant, H.; Kernan, M.; Reynolds, B.; Shilland, E. Nitrogen saturation in UK moorlands: The critical role of bryophytes and lichens in determining retention of atmospheric $\mathrm{N}$ deposition. J. Appl. Ecol. 2005, 42, 507-517. [CrossRef]

20. Jones, M.L.M. Nitrogen Deposition in Upland Grasslands: Critical Loads, Management and Recovery. Ph.D. Thesis, University of Sheffield, Sheffield, UK, 2005.

21. Van Wijk, M.T.; Clemmensen, K.E.; Shaver, G.R.; Williams, M.; Callaghan, T.V.; Chapin, F.S.; Cornelissen, J.H.C.; Gough, L.; Hobbie, S.E.; Jonasson, S.; et al. Long-term ecosystem level experiments at Toolik Lake, Alaska, and at Abisko, Northern Sweden: Generalizations and differences in ecosystem and plant type responses to global change. Glob. Change Biol. 2003, 10, 105-123. [CrossRef]

22. Soudzilovskaia, N.A.; Onipchenko, V.G.; Cornelissen, J.H.C.; Aerts, R. Effects of fertilisation and irrigation on foliar afterlife in alpine tundra. J. Veg. Sci. 2007, 18, 755-766. [CrossRef]

23. Shibata, H.; Kuboi, T.; Konohira, E.; Satoh, F.; Sasa, K. Retention processes of anthropogenic nitrogen deposition in a forest watershed in northern Japan, Proceedings of the 3rd International Nitrogen Conference, Beijing, China, October 2004; Zhu, Z., Minami, K., Xing, G., Eds.; Science Press USA: Princeeton Junction, NJ, USA, 2005; pp. 626-630.

24. Noguchi, M.; Yoshida, T. Tree regeneration in partially cut conifer-hardwood mixed forests in northern Japan: Roles of establishment substrate and dwarf bamboo. For. Ecol. Manage. 2004, 190, 335-344. [CrossRef]

25. Toyooka, H. Sasa growing in Hokkaido as biomass resources. Bamboo J. 1983, 1, 22-24.

26. Watanabe, T.; Fukuzawa, K.; Shibata, H. Temporal changes in litterfall, litter decomposition and their chemical composition in Sasa dwarf bamboo in a natural forest ecosystem of northern Japan. J. For. Res. 2013, 18, 129-138. [CrossRef]

27. Ozawa, M.; Shibata, H.; Satoh, F.; Sasa, K. Effect of surface soil removal on dynamics of dissolved inorganic nitrogen in snow-dominated forest soil. Scientific World J. 2001, 1, 527-533. [CrossRef] [PubMed]

28. Shibata, H.; Ozawa, M.; Satoh, F.; Sasa, K. The effect of treatment for land surface during forest practice on soil nitrogen dynamics. J. Jpn. For. Soc. 2007, 89, 314-320. [CrossRef]

29. Shibata, H.; Toda, H.; Fukushima, K.; Tanio, Y.; Takahashi, T.; Yoshida, T. Relationship between biogeochemical processes and forest management in Japanese forest ecosystems. J. Jpn. For. Soc. 2009, 91, 408-420. [CrossRef]

30. Fukuzawa, K.; Shibata, H.; Takagi, K.; Nomura, M.; Kurima, N.; Fukazawa, T.; Satoh, F.; Sasa, K. Effect of clear-cutting on nitrogen leaching and fine root dynamics in a cool-temperate forested watershed in northern Japan. For. Ecol. Manage. 2006, 225, 257-261. [CrossRef] 
31. Fukuzawa, K.; Shibata, H.; Takagi, K.; Satoh, F.; Koike, T.; Sasa, K. Roles of dominant understory Sasa bamboo in carbon and nitrogen dynamics following canopy tree removal in a cool-temperate forest in northern Japan. Plant. Spec. Biol. 2015, 30, 104-115. [CrossRef]

32. Chapin, F.S. The mineral nutrition of wild plants. Annu. Rev. Ecol. Syst. 1980, 11, 233-260. [CrossRef]

33. Kikuzawa, K. A cost-benefit analysis of leaf habit and leaf longevity of trees and their geographical pattern. Am. Nat. 1991, 138, 1250-1263. [CrossRef]

34. Killingbeck, K.T. Nutrients in senesced leaves: Keys to the search for potential resorption and resorption proficiency. Ecology 1996, 77, 1716-1727. [CrossRef]

35. Magill, A.H.; Aber, J.D.; Hendricks, J.J.; Bowden, R.D.; Melillo, J.M.; Steudler, P.A. Biogeochemical response of forest ecosystems to simulated chronic nitrogen deposition. Ecol. Appli. 1997, 7, 402-415. [CrossRef]

36. Magill, A.H.; Aber, J.D.; Berntson, G.M.; McDowell, W.H.; Nadelhoffer, K.J.; Melillo, J.M.; Steudler, P. Long-term nitrogen additions and nitrogen saturation in two temperate forests. Ecosystems 2000, 3, 238-253. [CrossRef]

37. Huang, J.Y.; Zhu, X.G.; Yuan, Z.Y.; Song, S.H.; Li, X.; Li, L.H. Changes in nitrogen resorption traits of six temperate grassland species along a multi-level $\mathrm{N}$ addition gradient. Plant Soil. 2008, 306, 149-158. [CrossRef]

38. Huang, J.Y.; Yu, H.L.; Wang, B.; Li, L.H.; Xiao, G.J.; Yuan, Z.Y. Nutrient resorption based on different estimations of five perennial herbaceous species from the grassland in inner Mongolia, China. J. Arid. Environ. 2012, 76, 1-8. [CrossRef]

39. Loladze, I. Rising atmospheric $\mathrm{CO}_{2}$ and human nutrition: Toward globally imbalanced plant stoichiometry? Trends Ecol. Evol. 2002, 17, 457-461. [CrossRef]

40. Reich, P.B.; Hobbie, S.E.; Lee, T.; Ellsworth, D.S.; West, J.B.; Tilman, D.; Knops, J.M.H.; Naeem, S.; Trost, J. Nitrogen limitation constrains sustainability of ecosystem response to $\mathrm{CO}_{2}$. Nature 2006, 440, 922-925. [CrossRef] [PubMed]

41. Berg, B.; Matzner, E. Effect of $\mathrm{N}$ deposition on decomposition of plant litter and soil organic matter in forest ecosystem. Environ. Rev. 1997, 5, 1-25. [CrossRef]

42. Hobbie, S.E. Contrasting effects of substrate and fertilizer nitrogen on the early stages of litter decomposition. Ecosystems 2005, 8, 644-656. [CrossRef]

43. Nadelhoffer, K.; Downs, M.; Fry, B.; Magill, A.; Aber, J.D. Controls on N retention and exports in a forested watershed. Environ. Monit. Assess. 1999, 55, 187-210. [CrossRef]

44. Nadelhoffer, K.J.; Emmett, B.A.; Gundersen, P.; Kjønaas, O.J.; Koopmans, C.J.; Schleppi, P.; Tietema, A.; Wright, R.F. Nitrogen deposition makes a minor contribution to carbon sequestration in temperate forests. Nature 1999, 398, 145-148. [CrossRef]

45. Forest Soil Division. Classification of forest soil in Japan (1975). Bul. Gov. For. Exp. Sta. 1976, 280, 1-28.

46. FAO. Soil Map of the World. Revised Legend; Reprinted with corrections 1990. World Soil Resources Reports 60; ISRIC: Wageningen, The Netherlands, 1997; p. 140.

47. Wakamatsu, T.; Sato, K.; Takahashi, A.; Shibata, H. Proton budget for a Japanese cedar forest ecosystem. Water. Air. Soil. Poll. 2001, 130, 721-726. [CrossRef]

48. Saitoh, T.; Seiwa, K.; Nishikawa, A. Effects of resource heterogeneity on nitrogen translocation within clonal fragments of Sasa palmata: An isotopic $\left({ }^{15} \mathrm{~N}\right)$ assessment. Ann. Bot. 2006, 98, 657-663. [CrossRef] [PubMed]

49. Saitoh, T.; Seiwa, K. Physiological integration of clonal plants: Resource acquiring strategies in clonal fragments of a dwarf bamboo, Sasa palmata. Jpn. J. Ecol. 2007, 57, 229-237. (In Japanese)

50. Giblin, A.E.; Laundre, J.A.; Nadelhoffer, K.J.; Shaver, G.R. Measuring nutrient availability in arctic soils using ion exchange resins: A field test. Soil. Sci. Soc. Am. J. 1994, 58, 1154-1162. [CrossRef]

51. Bormann, F.H.; Likens, G.E. Pattern and Processes in a Forested Ecosystem; Springer: New York, NY, USA, 1979.

52. Goodale, C.L.; Aber, J.D. The long-term effects of land-use history on nitrogen cycling in northern hardwood forests. Ecol. Appli. 2001, 11, 253-267. [CrossRef]

53. Chen, Y.; Högberg, P. Gross nitrogen mineralization rates still high 14 years after suspension of $\mathrm{N}$ input to a N-saturated forest. Soil. Biol. Biochem. 2006, 38, 2001-2003. [CrossRef]

(C) 2016 by the authors; licensee MDPI, Basel, Switzerland. This article is an open access article distributed under the terms and conditions of the Creative Commons Attribution (CC-BY) license (http://creativecommons.org/licenses/by/4.0/). 